\title{
The Risk Factors Analysis Occurrence of Chlamydia Infection to Direct Female Seks Workers (DFSW) in Indonesia
}

\author{
Masayu Gemala Rabiah $^{1,}$ Rini Mutahar ${ }^{1 *}$ and Rico Januar Sitorus ${ }^{1}$ \\ ${ }^{2}$ Faculty of Public Health, Universitas Sriwijaya, Ogan Ilir, Sumatera Selatan, Indonesia
}

\begin{abstract}
Chlamydia infection is one of the most common sexually transmitted infections worldwide. Based on data of IBBS 2015 in Indonesia, the highest prevalence of chlamydia occurred in direct female sex worker group (32.21\%). This study a STIs to determine the risk factors for chlamydia infection in direct sex workers. This research uses CrossSectional study design. The population of this study were all direct female sex workers as many as 3,789 people with samples in accordance with inclusion and exclusion criteria as many as 3.114 people. The prevalence of direct female sex workers with chlamydia infection was $1.018(32.4 \%)$. The result of the analysis showed that there was a relationship between age (PR: 0.541 95\% CI: 0.456-0.643) and length of work as FDSW (PR: 1,.60, $95 \%$ CI: 1.087-1.512) chlamydia infection in female sex workers in Indonesia. most dominant variable has an effect on the incidence of chlamydia infection that is long working as FDSW after controlled by age (PR 1.282 95\% CI: 1.087-1,.12). It is expected for the government to improve the implementation of prevention program of chlamydia not only among female sex worker but also proactive to customer.
\end{abstract}

\section{Introduction}

Chlamydia Infection is the infection that is caused by more than 30 types of bacteria, viruses, parasites, and fungi which is transmitted through sexual relations both vaginal, anal and oral. However, transmission can also occur from mother to the fetus in the womb or at birth, through blood products, or medical contaminated transfer. STIs can be classified in two type based on how it is cured, the first one is STIs that can be cured such as syphilis, gonorrhea, chlamydia, trichomonoasis. The other one is STIs that can not be cured like hepatitis B, herpes, Human Immunodeficiency Virus/HIV, dan Human Papiloma Virus/HPV.[1,2]

The Data from World Health Organization (WHO) shows that more than 1 million STIs are obtained every day and there are an estimated 357 million STIs (Chlamydia, Gonorrhea, Syphilis and Trichomoniasis), 131 million of which are the incidence of Chlamydia infections that occured every year in the age group 15-49 year.[3] This sexually transmitted

\footnotetext{
${ }^{*}$ Corresponding author: rini_mutahar@fkm.unsri.ac.id
} 
infection (STI) is one of the causes of health, social and economic problems in many countries including Indonesia.

Chlamydia infection is one of the most common sexually transmitted infections worldwide.[4.5] In America more than 3 million new cases are reported annually, of which $70-90 \%$ are asymptomatic, because of the high rate of infection that is asymptomatic the true prevalence of infection can be higher.[6] Based on the Biological and Behavioral Survey 2015, in Indonesia the highest prevalence of chlamydia was in the DFSW group $(32.21 \%)$, followed by the IFSW group (30.29\%), MSM (18.53\%) and Transgender $(16.78 \%$ ) From these data shows that sexual chlamydia infection is the most common among direct female sex workers (DFSW).[1]

Female sex workers is a core group in STIs transmission. Through the development of the epidemic, pathogens spread from the core group, female sex workers, directly to the customer population. Population this customer will transmit the disease to sexual partner in the common population, thus forming the chain of transmission of chlamydia infection.[1] This infection is very influenced by behavior and style patterns someone's life [7] Some other risk factors are new or multiple sexual partners. Inconsistent contraceptive use, commercial sex workers, low education status and unmarried status[8]

The purpose of this research is to know the factors that influence the incidence of chlamydia infection in direct female sex workers in several major cities in Indonesia with analysis secondary data Integrated Biological and Behavioral Survey (IBBS) 2015 was carried out by the Ministry of poor living conditions Health Affairs.

\section{Materials and Methods}

The design of this research was cross sectional study by using secondary data sources from the 2015 Integrated Biological and Behavioral Survey (IBBS). The independent variables in this study were age, marital status, education level, age at the first sex, number of customers, frequency of sex, consistency of condom used, consistency of vaginal douching, and long working as a direct female sex worker while the dependent variable is the incidence of Chlamydia Infection. The target population in this study were all direct female sex workers in Indonesia.

The inclusion criteria in this study were direct female sex workers who were 15 years of age or older who had commercial sex with at least one customer in the last month and were at the survey site at the time of the survey team's visit, while the exclusion criteria in this study namely incomplete or missing data. The minimum sample size is 260 respondents, after the exclusion criteria were carried out, the total sample in this study was 3.143 respondents. Statistics data analysis using computer software included univariate, bivariate and multivariate (regression logistics prediction factor model ). 


\section{Results and Discussions}

Table 1. Dependent and Independent Variable Frequency Distribution

\begin{tabular}{|c|c|c|}
\hline Variable & Amount (n) & Percentage (\%) \\
\hline $\begin{array}{c}\text { Chlamydia Infection } \\
\text { Yes No }\end{array}$ & $\begin{array}{l}1018 \\
2125\end{array}$ & $\begin{array}{l}32.4 \\
67.6 \\
\end{array}$ \\
\hline $\begin{array}{c}\text { Age } \\
<25 \text { years } \\
\geq 25 \text { years } \\
\end{array}$ & $\begin{array}{c}781 \\
2362 \\
\end{array}$ & $\begin{array}{l}24.8 \\
75.2 \\
\end{array}$ \\
\hline $\begin{array}{c}\text { Marital Status } \\
\text { Single Married Divorced Death divorce } \\
\text { No answer }\end{array}$ & $\begin{array}{c}488 \\
527 \\
1819 \\
307 \\
2 \\
\end{array}$ & $\begin{array}{c}15.5 \\
16.8 \\
57,9 \\
9.8 \\
1 \\
\end{array}$ \\
\hline $\begin{array}{c}\text { Level of Education } \\
\text { Never go to school } \\
\text { Not completing elementary school / equivalent } \\
\text { Graduated from elementary school } \\
\text { Not graduating from junior high school / equivalent } \\
\text { Graduated from junior high school / equivalent Not } \\
\text { graduating from high school or equivalent Graduated } \\
\text { from high school / equivalent } \\
\text { Academy / College }\end{array}$ & $\begin{array}{c}130 \\
482 \\
774 \\
358 \\
823 \\
188 \\
365 \\
23\end{array}$ & $\begin{array}{c}4.1 \\
15.3 \\
24.6 \\
11.4 \\
26.2 \\
6.0 \\
11.6 \\
7\end{array}$ \\
\hline $\begin{array}{l}\text { First time } \mathbf{s e x} \\
\quad<20 \text { years } \\
\geq 20 \text { years }\end{array}$ & $\begin{array}{c}2500 \\
643\end{array}$ & $\begin{array}{l}79.5 \\
20.5\end{array}$ \\
\hline $\begin{array}{c}\text { Number of Customers } \\
\geq 5 \text { people } \\
<5 \text { people }\end{array}$ & $\begin{array}{l}1913 \\
1230\end{array}$ & $\begin{array}{l}60.9 \\
39.1\end{array}$ \\
\hline $\begin{array}{c}\text { Frequency of Sex } \\
\geq 5 \text { times } \\
<5 \text { times }\end{array}$ & $\begin{array}{l}2129 \\
1014\end{array}$ & $\begin{array}{l}67.7 \\
32.3\end{array}$ \\
\hline $\begin{array}{c}\text { Consistency of Condom Use } \\
\text { Inconsistent } \\
\text { Consistent } \\
\end{array}$ & $\begin{array}{l}1971 \\
1172 \\
\end{array}$ & $\begin{array}{l}62.7 \\
37.3 \\
\end{array}$ \\
\hline $\begin{array}{l}\text { Vaginal Douching Consistency } \\
\text { Consistent Inconsistent }\end{array}$ & $\begin{array}{l}1999 \\
1144 \\
\end{array}$ & $\begin{array}{l}63.6 \\
36.4\end{array}$ \\
\hline $\begin{array}{c}\text { Working Period of DFSW } \\
\quad \geq 4 \text { years } \\
<4 \text { years }\end{array}$ & $\begin{array}{l}1143 \\
2000\end{array}$ & $\begin{array}{l}36.4 \\
63.6 \\
\end{array}$ \\
\hline
\end{tabular}

Based on Table 1. direct female sex workers (DFSW) who were infected with chlamydia were $32.4 \%$, the majority of DFSW were more than 25 years old at $75.2 \%$, the majority of respondents were divorced as much as $57.9 \%$, the majority of direct female sex worker education level graduated from junior high school as much as $26.2 \%$, most DFSW have sex for the first time at the age of less than 20 years as much as $79,5 \%$, the majority DFSW get customers in the past one week more than 5 people by $60.9 \%$. Most of the direct female sex workers had sex frequency in the past week more than 5 times, namely $67.7 \%$. The majority of direct female sex workers have not consistently used condoms in the past 
week as much as $62.7 \%$. A total of $63.6 \%$ of female sex workers were immediately consistent in performing vaginal douching in the past week. The majority of respondents work as DFSW less than 4 years, which is $63.6 \%$ (Table 1).

Table 2 . Relationship of Independent Variable with Chlamydia Infections in Direct Female Sex Workers in Indonesia

\begin{tabular}{|c|c|c|c|c|c|c|c|c|}
\hline \multicolumn{9}{|c|}{ Chlamydia Infection } \\
\hline \multirow[t]{2}{*}{ Variable } & Yes & & No & & \multicolumn{2}{|l|}{ Total } & \multirow[t]{2}{*}{ p-value } & PR 95\% CI \\
\hline & $\mathbf{n}$ & $\%$ & $\mathbf{n}$ & $\%$ & $\mathbf{N}$ & $\%$ & & \\
\hline $\begin{array}{c}\text { Age } \\
<25 \text { years }\end{array}$ & 344 & 44.0 & 437 & 56.0 & 781 & 100 & $<0.0001^{*}$ & 1.544 \\
\hline$\geq 25$ years & 674 & 28.5 & 1688 & 71.5 & 2362 & 100 & & $1.394-1.709$ \\
\hline \multicolumn{9}{|l|}{ Marital status: } \\
\hline Single & 870 & 33.3 & 1746 & 66.7 & 2616 & 100 & \multirow{2}{*}{$0.024^{*}$} & 1.184 \\
\hline Married & 148 & 28.1 & 379 & 71.9 & 527 & 100 & & $1.022-1.372$ \\
\hline \multicolumn{9}{|c|}{ Level of education } \\
\hline $\begin{array}{c}\text { Low } \\
(<\text { High school })\end{array}$ & 871 & 31.6 & 1884 & 68.4 & 2755 & 100 & $0.016^{*}$ & $\begin{array}{c}0.834 \\
0.726-0.959\end{array}$ \\
\hline High & 147 & 37.9 & 241 & 62.1 & 388 & 100 & & \\
\hline \multicolumn{9}{|l|}{ (> High School) } \\
\hline \multicolumn{9}{|l|}{ First Time Sex } \\
\hline$<20$ years & 828 & 33.1 & 1672 & 66.9 & 2500 & 100 & 0.093 & 1.121 \\
\hline$\geq 20$ years & 190 & 29.5 & 453 & 70.5 & 643 & 100 & & $0.983-1.279$ \\
\hline \multicolumn{9}{|l|}{ Number of } \\
\hline \multicolumn{9}{|l|}{ Customers } \\
\hline$\geq 5$ people & 627 & 32.8 & 1286 & 67.2 & 1913 & 100 & 0.590 & 1.031 \\
\hline$<5$ people & 391 & 31.8 & 839 & 68.2 & 1230 & 100 & & $0.929-1.144$ \\
\hline \multicolumn{9}{|c|}{ Frequency of Sex } \\
\hline$\geq 5$ times & 716 & 33.6 & 1413 & 66.4 & 2129 & 100 & \multirow{2}{*}{$0.035^{*}$} & 1.129 \\
\hline$<5$ times & 302 & 29.8 & 712 & 70.2 & 1014 & 100 & & $1.010-1.263$ \\
\hline \multicolumn{9}{|l|}{ Consistency of } \\
\hline \multicolumn{9}{|l|}{ Condoms Use } \\
\hline Inconsistent & 657 & 33.3 & 1314 & 66.7 & 1971 & 100 & 0.154 & 1.082 \\
\hline Consistent & 361 & 30.8 & 811 & 69.2 & 1172 & 100 & & $0.973-1.203$ \\
\hline \multicolumn{9}{|c|}{ Vaginal Douching } \\
\hline \multicolumn{9}{|c|}{ Consistency } \\
\hline Consistent & 638 & 31.9 & 1361 & 68.1 & 1999 & 100 & 0.478 & 0.961 \\
\hline Inconsistent & 380 & 33.2 & 764 & 66.8 & 1144 & 100 & & $0.866-1.066$ \\
\hline \multicolumn{9}{|c|}{ Working Period of } \\
\hline $\begin{array}{c}\text { DFSW } \\
\geq 4 \text { years }\end{array}$ & 310 & 27.1 & 833 & 72.9 & 1143 & 100 & $<0.0001^{*}$ & 0.766 \\
\hline$<4$ years & 708 & 35.4 & 1292 & 64.9 & 2000 & 100 & & $0.685-0.885$ \\
\hline
\end{tabular}

* Significant at 5\% alpha

The results of the bivariate analysis show that the variables associated with the incidence of chlamydia infection in direct female sex workers included Age ( $P R=1.544)$, Marital Status $(\mathrm{PR}=1.184)$, Level of Education $(\mathrm{PR}=0.834)$, Frequency of Sex $(\mathrm{PR}=$ $1.129)$, and the duration worked as a DFSW $(\mathrm{PR}=0.766)$. While the unrelated variables were the age of first sex, number of customers, consistency of condom use, and consistency of vaginal douching (Table2). 
Table 3. Multivariate Analysis Results

\begin{tabular}{|c|c|c|c|c|c|c|}
\hline \multirow[t]{2}{*}{ Variable } & \multicolumn{3}{|c|}{$\begin{array}{c}\text { Early Modeling of Multivariate } \\
\text { Analysis }\end{array}$} & \multicolumn{3}{|c|}{$\begin{array}{c}\text { Final Model of Multivariate } \\
\text { Analysis }\end{array}$} \\
\hline & p-value & PR & $95 \%$ CI & p-value & PR & $95 \%$ CI \\
\hline Age & $<0.0001$ & 0.562 & $0.471-0.670$ & $<0.0001$ & 0.541 & $0.456-0.643$ \\
\hline Marital status & 0.117 & 0.845 & $0.685-1.043$ & - & - & - \\
\hline Education Level & 0.051 & 1,253 & $0.999-1.570$ & - & - & - \\
\hline First time sex & 0.589 & 0.947 & $0.779-1.152$ & - & - & - \\
\hline Frequency of Sex & 0.233 & 0.904 & $0.767-1.067$ & - & - & - \\
\hline $\begin{array}{l}\text { Consistency of } \\
\text { Condoms }\end{array}$ & 0.256 & 0.912 & $0.779-1.069$ & - & - & - \\
\hline $\begin{array}{c}\text { Working period } \\
\text { as a DFSW }\end{array}$ & 0.006 & 1.260 & $1.067-1488$ & 0.003 & 1.282 & $1.087-1.512$ \\
\hline
\end{tabular}

The results of the analysis show that the most dominant variable influencing the incidence of chlamydia infection in direct female sex workers was the duration of work as DFSW after being controlled by the age variable. The result of the analysis is known by the table above that the time working variable as DFSW obtained the largest PR value of 1.282 (95\% CI: 1.087-1.512). Direct female sex workers who work more than 4 years 1.282 times higher risk of chlamydia infection compared to direct female sex workers who work less than 4 years (Table 3 ).

The data which used by researchers in analyzing the risk factors for the incidence of chlamydia infection in direct female sex workers in Indonesia are data from the 2015 Integrated Biology and Behavior Survey (IBBS) with cross sectional design in order to collect data of STBP respondent. The deficiency of this research is the study design is difficult seeing the causal relationship or in explaining which conditions are first of a condition of health problems studied because of the measurement of variables carried out at the same time. Another deficiency in this study is using secondary data that have different purposes from the research purposes.

\subsection{Occurrence of Chlamydia Infection}

Chlamydia infection is the most common sexually transmitted infection in the world. This infection occurs without symptoms that typically distinguish cervicitis due to Chlamydia trachomatis and cervicitis due to other organisms. The high level of asymptomatic infection is one of the factors that influence the prevalence of infections that can actually be higher [3].

Direct female sex worker is a core group in STI's transmission.[1] Factor of risk for chlamydia infection in female sex workers directly, among others, the young ( $<25$ years), sexual partner with urethritis, multiple sex partners, swab endocervical cause bleeding, presence of secretions endocervical mucopurulent, contraceptives such as condoms inconsistently or not using condoms during sex, low educational status and unmarried status[9] The prevalence of direct female sex workers who experienced chlamydia infection was 1.018 respondents ( $32.4 \%$ ) and who did not experienced chlamydia infection 2.125 respondents $(67.6 \%)$.

\subsection{Age of Direct Female Sex Workers}

In this study shows that the majority of of DFSW aged $<25$ years with chlamydia infection was $44 \%$. Based on the chi-square calculation, the $p$-value is $<0.0001$ ( $p$-value 
$<0.05)$. Respondents with age less than 25 years has an opportunity of 1.544 times to be at risk of developing chlamydia infection compared with respondents over the age of 25 years.

The results of this study are supported by Puspita (2017) which states that there is a significant relationship between age with the incidence of chlamydia infection ( $p$-value $=$ 0.012) OR value of 3.683. [9] Young age (less than 25 years) is the most powerful factor associated with Chlamydia infection there are direct female sex workers.[10,15] This can be explained by anatomical differences in the cervix of a younger woman, where the junction is squamo-columnar, the main host target for $C$. trachomatis which is everted and thus more open. $[8,19]$ Marcone et.al research in Rome states that age factors are associated with the incidence of Chlamydia Infection. Women with age less than 25 years were more at risk of developing chlamydia infection compared to women aged more than 25 years (OR: 2.33 95\% CI: 1.02- 5.31; $\mathrm{p}=0.04$ )[11].

\subsection{Marital Status}

The result of this study indicate that status of marriage is a risk factor for the incidence of chlamydia infection. On status variables marriage obtained a PR value of 1.184 means that respondents who are not married / divorced have a risk of 1.184 times for the risk of developing chlamydia infection compared with respondents with married status $(95 \% \mathrm{CI}$ : 1.033-1.372) [12].

This research is also in line with research conducted in Indonesia in 2017 which states there is a relationship between marital status and the incidence of chlamydia infection ( $\mathrm{p}$ value $=0.035)$ with an OR value of $(3.18995 \% \text { CI: } 1.1-8.5)^{[9]}$ Supported by research in India in 2013 which showed that status divorced and unmarried related with sexual risk OR 3.24, 95\% CI: $1.63-6.43$ [13].

Unmarried status can increase the risk of getting STIs includes chlamydia infection compared to married respondents.[23,24] Unmarried status affect sexual needs to be higher compared to someone who has already get married, so it increases the risk of not having sex safe with a partner who can transmit chlamydia infection [9].

\subsection{Level of Education}

A person who is educated has a wider possibility to be able to find information, receive and access various information, especially about the importance and whether or not prevention of chlamydia infection. [14,25] The results of this study indicate that majority of respondents with low education experienced an incidence of chlamydia infection $(31.6 \%)$. This is evidenced by the results of statistical tests with $p$-value $(0.016<0.05)$.

The result of this study is in line with the research conducted by [9] which states that there is a relationship between the level of education and the incidence of chlamydia infection ( $\mathrm{p}$-value $=0.040$ ). The value of $\mathrm{OR}$

is 3.193( 95\% CI: 1.16-8.74).[9] However, the result of this study contrast with research in Indonesia which states that there is no relationship between the level of education and the incidence of chlamydia infection (p-value 0.727 OR 1.06 95\% CI : 0.74-1.51)[16].

Education related to someone's ability to accept and to respond information. In the health side, education factor is classified as individual predisposing factors to utilize health facilities that are due to differences in things knowledge of health, value, and the individual's attitude. Therefore, the sensitivity in facing and overcoming a health problem will be better and ripe than someone with a low education [25]. 


\subsection{Frequency of Sex}

Frequency of sexual intercourse DFSW have done in the past week. The higher frequency of sex in the past week, the greater the risk of STIs. This is because of the increased chance of contracting STIS at each sexual frequency. [14,21] This study shows that the frequency of having sex more than 5 times per week increases the risk of chlamydia infection

1.129 times higher. However, this research contrasts with [20] study which states that there is no relationship between the frequency of having sex with the incidence of chlamydia infection $(\mathrm{OR}=1.21 ; 95 \% \mathrm{CI}=0.51$ to $2.86 ; \mathrm{p}=0.661)[18-22]$.

However, based on the result of the multivariate analysis, it was obtained to see the relationship between the frequency of sex and the incidence of chlamydia infection by analyzing other covariates. Statistical test result showed that there was no relationship between the frequency of having sex with the incidence of chlamydia infection ( $p$-value 0.233; PR 0.904; 95\% CI: 0.767-1.067).

\subsection{Working Period as a Direct Female Sex Worker (DFSW)}

The duration of work as DFSW is one of the important factors related to the incidence of chlamydia infection. The longer the service period of a DFSW, the higer possibility serving customers who have been infected with chlamdiasis. [17,20] The risk of transmission can increase along with the length of time to become DFSW. Chlamydia infection transmission can continue to increase along with the start of work to become DFSW. Becoming a sex worker may not be a living well job, there is the time when DFSW will stop and the number of their customers decreases.

Length work as DFSW is a protective factor against the incidence of chlamydia infection. In the working time variable as DFSW obtained the value of PR 0.766 means that the respondents with a working period of more than 4 years prevents 0.766 times to experience chlamydia infection compared to respondents with less than 4 years of work.

Based on the result of the multivariate analysis obtained to see the old working relationship as DFSW with incidence of chlamydia infection by analyzing other covariates. The results of statistical tests showed that the duration of work as DFSW was the most dominant factor affecting the incidence of chlamydia infection ( $\mathrm{p}$-value $=0.003 ; \mathrm{PR}=$ $1.22895 \%$ CI : 1.087-1.512). Direct female sex workers who work less than 4 years 1,282 times higher risk for chlamydia infection compared to direct female sex workers working directly over 4 years.

\section{Conclusions}

There is a significant relationship between age, marital status, level of education, frequency of sex, working period as DFSW and no relationship between the first age of sex, number of customers, consistency of condoms and consistency of vaginal douching with the incidence of chlamydia infection in direct sex workers in Indonesia. The most dominant variable effect on the incidence of chlamydia in infection of women direct sex workers are working period as Direct Female Sex Worker (DFSW) with PR value 1.282 (95\% CI: 1.087-1.512).

For the government, it is better to improve the implementation of prevention and control programs for chlamydia infections to reduce the prevalence of chlamydia infections not only among women who are direct sex workers but also need to be carried out proactively to customers in order to increase awareness in women of direct sex workers at the risk of 
chlamydia infection, provide capacity building training programs and increase the awareness of the importance of education and provide facilities health services for diagnosis and developing STI clinics at the location / localization of sex workers.

\section{References}

1. Kemenkes RI., Pedoman Penatalaksanaan Infeksi Menular Seksual (Dirjen Pengendalian Penyakit dan Penyehatan Lingkungan, Jakarta, 2015)

2. WHO, Factsheet of Sexually Transmitted Infections (2013)

3. WHO, Global Health Sector Strategy On Sexually Transmitted Infections 2016-2021 (2016)

4. Paavonen J., Ann Med. J. state of the art 44, 1 (2012)

5. WHO, Prevalence and incidence of selected sexually transmitted infections, Chlamydia trachomatis, Neisseria gonorrhoeae, syphilis and Trichomonas vaginalis: methods and results used by WHO to generate 2005 estimates (Geneva, WHO, 2011)

6. Murtiastutik D., Infeksi Chlamydia pada wanita. Buku ajar infeksi menular seksual (Airlangga University Press, Surabaya, 2008)

7. Widodo, E., J. Jpki, 2 (2009)

8. Novak M., Novak D., J. Srh 4, 4 (2013)

9. Puspita, Linda, Jik 2, 1 (2017)

10. Darville T., J. Spid 1, 2 (2008)

11. Marcone, V et al., Es, 17, 25 (2012)

12. Lanjouw, E et al., 0, 0 (2015)

13. Malhotra, Meenakshi et al. Ijmr, J. Genital Chlamydia Trachomatis : An Update 30, 2 (2013)

14. Notoadmodjo, S., Promosi Kesehatan dan Perilaku Kesehatan. (Rineka Cipta, Jakarta, 2012)

15. Arifin, Fitriana N, Praba G, Ari U 1, 2 (2012)

16. Widiastuti, Yani, et al., Kesehatan Reproduksi (Yogyakarta, 2009)

17. Karmila, Nelva, Infeksi Chlamydia Trachomatis (Fakultas Kedokteran, Universitas Sumatera Utara, 2011)

18. Kusnan, Adius. Jk. 4, 2 (2013)

19. Aridawarni, Yulica,Jos. $A$ 2, 1 (2014)

20. Nugrahaeni, Anita et al., Jeph, J. Risk Factor of Gonnorrhoea Among Female Indirect Sex Worker 2, 3 (2017)

21. Setyawulan, Hubungan praktek Pencegahan Penyakit Menular Seksual dengan Kejadian Penyakit Menular (2007)

22. Pane, M., Bppt, Aspek Klinis dan Epidemiologi Penyakit (2008)

23. Depkes RI., Surveilans Terpadu Biologi dan Perilaku (STBP, Jakarta, 2011)

24. Luong, Me-Linh et al., Jogc, Vaginal Douching, Bacterial vaginosis, adn Spontaneous Pretetm Birth 32, 4 (2010)

25. Mitchellc et al., Std 38, 12 (2011) 